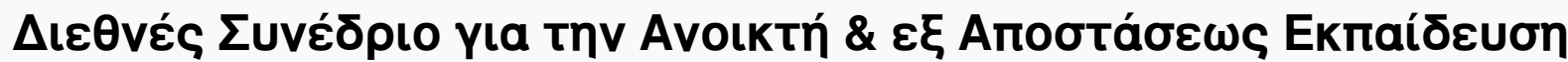

Tóp. 5, Ap. 2A (2009)

Open and Distance Education for Global Collaboration \& Educational Development

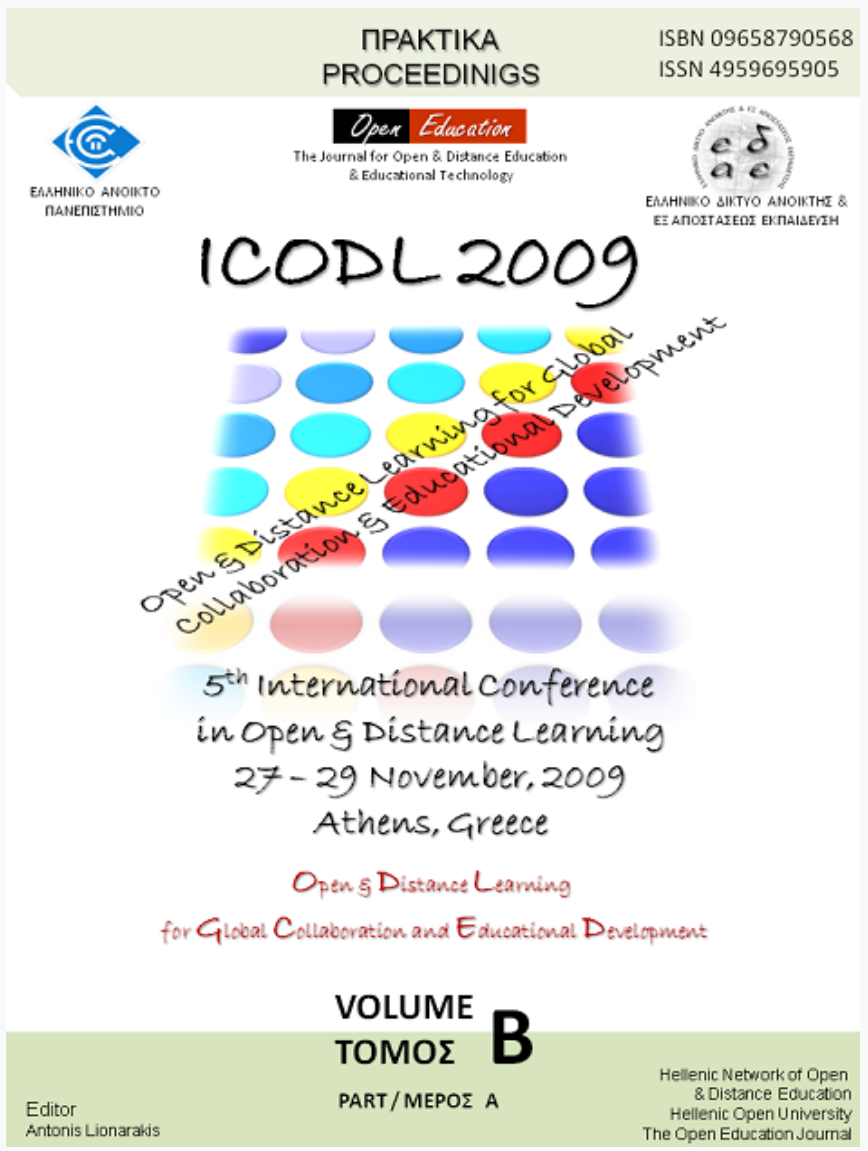

E-learning and internationalization implementation: Cross cultural analysis of higher education cases

Ulrike HUGL

doi: $10.12681 /$ icodl.461 


\title{
E-learning and internationalization implementation: Cross cultural analysis of higher education cases
}

\author{
Ulrike HUGL
}

School of Management,

University of Innsbruck, Innsbruck, Austria,

Universitaets strasse 15, A-6020 Innsbruck, Austria,

ulrike.hugl@uibk.ac.at

\begin{abstract}
Higher education in Asia and around the world is in a period of intense change including internationalisation, technological change, accountability, massification, managerial controls, financial support from public sources, and new regulations for comparability of degrees etc., all frame factors for adjustment on campus and milestones of cultural change in their respective societies. This paper presents two cases - an Austrian university case focusing on the implementation process of an e-learning strategy; and an US case examining the implementation of a university internationalisation initiative. Based on the two cases 'imperatives for change' are analysed and compared in areas of leadership, changing mission and vision, organisational capacity, and relationships to stakeholders. Results show that: a) leadership and the language of leadership play an important role in helping/making the university change, b) the mid level managers directly influence the rate of change, c) organisational challenges alter behaviour by increasing incentive rewards and, d) a major buy-in point for university faculty come from the perception that the change results in gains for students.
\end{abstract}

\section{Introduction}

"We live in a period of rapid change in higher education, a period when we can learn much from the experience of others. [...] Academic leaders worldwide worry about the same set of topics. Specific conditions may vary from one country to another, and there are certainly major differences between the Netherlands and Mali. Yet, solutions from one country may be relevant, at least in terms of suggesting alternatives, elsewhere (Altbach \& Peterson, 1999).

Higher education is in a period of intense change-this has become a mantra; sometimes so clearly true and overwhelming that it receives only the shoulder shrug of restating the obvious. Perhaps it is significant that the shoulder shrug, a non verbal communication with deeper cultural and social implications is a signature response, since all educational institutions are rooted in their society context. Some scholars (e.g. Altbach, 2000; Lee, 2004; Ravinet, 2008; Deem, Mok, \& Lucas, 2008; Lee, 2008; Hawkins, 2008; Willis, Yamamura, \& Rappleye, 2008; Park \& Niyozov, 2008; Tham \& Kam, 2008; Power, 2009) point to differing conditions and change efforts across different nations such as: globalisation, competition, massification, managerial control, deteriorating financial support from public sources, emerging globalised knowledge economies, and other changes such as the new regulations for comparability of degrees within the European Union - the so called 'Bologna Process' (e.g. Enders, 2000; Mechtenberg \& Strausz, 2008; Cardoso, Porela, Sá, \& Alexandre, 2008; Fejes, 2008; Damme van, 2009; Jakobi \& Rusconi, 2009).

Higher education change in countries in the Asia Pacific, like elsewhere, has been greatly dependent on leadership and the perceived adaptability of the sponsoring society. Whether intent on effecting a stated national policy of economic competiveness or aims of raising standards of living, higher education reform and change have been agendas from China to Pakistan; from South Korea to India (e.g. Law, 2006; Riaz, 2006; Jung, 2006; Anchan, 2006). While examples of reform attempts abound, success has been elusive, therefore it is incumbent on scholars to explore and explicate models of apparent success. 
While much previous analysis has focused on conditions of academic employment especially issues of tenure, working conditions, and part time faculty workloads (e.g. Rice 1986; Taylor 1997) or on issues of regulatory change (e.g. Shattock, 2000; McLendon, 2003; Yonezawa, 2003; Hawkins, 2008); this article examines comparisons of university change in the areas of leadership, mission and vision, organisational capacity, and relationships to stakeholders - each clearly with overlapping concerns and related contextual issues.

Developed from qualitative data and the use of qualitative analysis significant emergent patterns for the field can be found: In Austria, where university change is deeply affected by university employment structures including tenure, change can be a function of instructional support. In the US, where public-financed universities capture increasingly fewer governmental resources due to a general decline in confidence from governmental and civic leaders, universities operate in highly visible public forums where change and adaptability are expected, and sometimes accomplished, without accompanying resources or political sources of support for university leadership and change. In each situation, questions are raised about the management and reformed organisational identity.

The Austrian case focuses on the implementation process of an e-Learning strategy: its genesis, pitfalls and changes. The implementation process is on-going, while simultaneously there is a challenge to develop the same curricula for bachelors' degree, master's degree, and $\mathrm{PhD}$ programs at 15 faculties, connecting them with the process of the e-learning strategy.

The US case examines the implementation of a university internationalisation initiative launched by both university leadership directive and faculty advocacy. The implementation, begun about nine years ago, has mobilized organisational resources, provided new avenues for faculty professional development and extended the arena for common ground between study and action in this public university, therefore increasing support for the university.

\section{Methodology}

For the following case studies traditional data collection methodologies were employed including: 1) participant observation, 2) the use of key informants, 3) interviews: both structured and unstructured, 4) the examination of artifacts, 5) event analysis and 6) unobtrusive measures. The author had access to respondents for interviews, policy statements, minutes, and other documents for review.

Use of qualitative data collection to develop case studies that examine culture contact in education was pioneered since 1992 by Sonia Nieto (2004) at the University of Massachusetts Amherst, who suggested that case studies afford opportunities to learn about issues of culture contact in educational organisation while analyzing them in their societal and cultural contexts.

\section{E-learning strategy and implementation at an Austrian university}

\section{The context}

With a population of about 8.3 million and an expanse of $83.871 \mathrm{~km}^{2}$ Austria has 22 common universities (the first university goes back to the year 1585), 19 universities of applied sciences and 7 private universities (e.g. www.statistik.at). The so-called Universities Act 2002 (2002) built the legal basis for the Austrian common universities (fully effective since $1^{\text {st }}$ January 2004). This regulation for the common Austrian universities 
"[...] has given the universities complete autonomy, (due to) instruments such as global budgets and performance agreements, etc. The universities were transformed to become legal entities under public law (previously federal establishments) and divested from the federal administrative system." (Kasparovsky \& Wadsack, 2004)

The legislation brought several challenges for Austrian universities: a) a new administrative system, b) a commitment by the Austrian state to provide the universities with funds in a three-year global formula-based budget (Melchior, 2004; Biedermann \& Strehl, 2004; Titscher, 2004; Höllinger, 2004), and c) a quality and performance management system in addition to new curriculum requirements. The scope of a degree program is indicated in terms of the credits established under the European Course Credit Transfer System (ECTS) as an important mobility-promoting instrument and information tool. (European Union, 2004; Vlâsceanu \& Voicu, 2006; Martínez \& Moreno, 2007) Every university must present in detail the range of its courses for all or certain degree programs and also the workload of a specific student.

Professors at an Austrian common university are responsible for research and teaching. They are in a limited or unlimited employment relationship to the university as full-time or part-time employees. Since January 2004, every university functions also as an employer; hence, all new staff members are employees of their university (Pechar, 2005).

\section{The European Bologna Process}

The Bologna Declaration of June 1999 (see e.g. http://ec.europa.eu/education/highereducation/doc1290_en.htm) put in motion a series of reforms to make European Higher Education both comparable and compatible, and more attractive and more competitive for EU-citizens and scholars from other continents. The so-called European Higher Education Area (EHEA) aims to facilitate mobility of students, graduates and higher education staff.

In 2005, the Bologna Process was extended to 45 signatory states and the reforms have been institutionalized in the European countries' laws. A conference of the ministers of higher education of the Bologna signatory states located in Bergen focused on mid-term achievements of the Bologna Process as well as standards and guidelines for quality assurance in the EHEA. Based on the Bergen Communique (European Commission, 2005) one of the ongoing priorities is "creating opportunities for flexible learning path in higher education". (Eurydice, 2005) A recent conference of the ministers highlighted again the importance of student-centred learning and mobility (Leuven Communiqué, 2009).

\section{E-learning strategy}

Flexible learning is becoming more important for the strategic development of Austrian universities. Organising and supporting learning processes of students in the digital age requires Austrian universities to improve ICT infrastructure, to offer training of teachers and students, and requires the implementation of the Bologna process and the development of an inter-institutional infrastructure. Since the 1990ies Austrian universities set up distance learning initiatives and programs. E-learning programs at the University of Innsbruck - mostly in the form of blended learning - provide learning content for all students, but especially for employed persons, handicapped persons as well as persons with care commitments, and persons in regions remote from universities interested in studying.

Based on a call from the Austrian Federal Ministry of Education, Science and Culture, the University of Innsbruck developed an e-learning strategy in 2005. At each 
of the 15 faculties (with about 23,000 students), the implementation process continues with challenges to develop the same curricula for bachelors', master's and $\mathrm{PhD}$ degree programs, and to connect them with the e-learning strategy.

\section{Case analysis}

To facilitate and accompany the e-learning strategy implementation process the ViceRector for Teaching and Students established a New Media Delegate-position tasked with promoting ICT at each faculty, coordinating e-learning activities of faculty and staff, submitting proposals for e-learning projects, reviewing of proposals, planning and coordinating further training for faculty members.

The e-learning strategy concentrated on the following: university-wide availability of technology (all courses automatically enrolled on the learning platform, videoconferencing, streaming technology, Wiki software, university-wide WIFIaccess); an 'e-learning team' supporting staff in developing professional content; flexible study programs or courses: basic courses of study programs with many students have to be made available as e-learning courses; and faculty development programs offering more than 20 different courses per year. An 'e-learning certificate' is issued to faculty members who have attended at least three of those courses. In addition, the elearning strategy included: a) a focal point in teaching and studying, with deans and faculty members having to achieve specific goals; b) a focus more on didactics and quality rather than cost cutting aspects; and c) implementation concepts differentiating several stages of virtualization (along the so-called 'Basler Model'; see Dittler \& Bachmann, 2003). Additional elements of effectiveness and value-added approaches were: learning elements correspond with didactical, pedagogical-psychological expertise and gender mainstreaming; organisational basic conditions ensure an integration of learning elements into teaching processes; and technology that is userfriendly and easy to apply.

\section{Case findings}

Pitfalls of technology-driven change-Reviewing the implementation process several pitfalls have to be considered. First, technology-based training is problematic, especially for the target group of external university teachers (e.g. handling the learning platform). Second, the prompt availability of training programs concerning newer tools (e.g. Wiki software) based on personal resources is also problematic. Third, results of several qualitative interviews show that faculty members regarded the e-learning strategy as a more 'technically-driven' implementation process with a user gap that has to be addressed: namely the assumption, that top management (the rectorate) is less 'didactically-oriented' than the faculty. Fourth, additional personnel resources for the existing e-learning team are necessary and crucial to ensure the implementation processes of professional courses.

Globalization issues - Since 1999 when the learning platform was launched there have been several efforts of content exchange. Also, due to a management change in the university system the original process diverged, as cooperation efforts arose with other universities in connection with master's degree programs. (It was mandated that each master's degree program had to have external university partners for a mutual exchange of teachers and curriculum modules.) With this e-learning content exchange came a new chance for improvement integral to wider or global connectedness.

Accountability - Both fiscal and workforce issues have provided indicators of program accountability. The strategy implementation process faced financial issues in the first years of implementation including a lack of infrastructure budget. While on the 
one hand 'enthusiastic' teachers used blended learning, on the other hand there also was resistance of others due to loosing interactive parts (courses to teach): In the Austrian system, teachers are usually paid for face-to-face teaching hours and there still is no acceptable regulation for payment of the resource-intensive set up of e-learning parts or for virtual support of students in e-learning concepts, therefore the issue of payment and accountability have emerged.

Competition-Besides the inter-organisational competition of Austrian and other universities in the field of e-learning content, intra-university level competition continues arising from the process of budget submission (for eLearning projects). Additionally, since January 2007 the student course evaluation includes e-learning specific questions on content quality, quality of virtual communication, and all evaluation results are available on the university homepage. These evaluations may have become also a factor of some faculty competition for higher course ratings.

Other related issues - included the annual monetary reward for teachers, the national system for career evaluation, and the transparency for funded e-learning projects. One problem of the e-learning implementation process is related to the careerrelevant evaluations of faculty members. These evaluations always have had their main focus on research performance (number and quality of publications). Addressing this practice is crucial to organisational change because a research focus on publications' performance (of especially younger staff) may hinder further improvement of teaching efforts and further implementation of professional e-learning concepts.

\section{The PSU case: Internationalisation at a US University}

\section{The context}

Portland State University (PSU) is a mid-sized public regional university located in Portland. It has about 25,000 students, of which two thirds are undergraduate and one third are graduate students. PSU was established during a post World War II higher education expansion period, in a national context where 'public university' did not indicate any federal funds exclusive of competitive research or training grants. PSU is now the largest public university in the State of Oregon, and the only urbanized metro area university for 1000 kilometres between San Francisco (California) and Seattle (Washington). The university has six colleges/schools of professional study.

During the last twenty years as PSU grew rapidly, with its developing urban mission (Frisbee, 1989) it has played increasingly larger roles in the metropolitan area, serving as a catalyst for building social capital and service learning. Due to its location and composition, the university must constantly compete in the State of Oregon for executive and legislative attention from sectional rivalries and historic traditions that have long dominated the fiscal resource allocation process. The university motto 'let knowledge serve the city' prominently displayed on a concrete skyway twelve meters above 'Broadway', a major city traffic public thoroughfare, has become a mantra for research and knowledge development agendas that both emerge from the local communities and inform practice in those communities, including municipal, county and state government. In the mid 1990s, the entire university faculty voted for a revision of the baccalaureate program that included service learning, interdisciplinary general education, and a senior capstone project mandating student (and faculty) involvement with community organisations. In 1997, with the succession of a new university president (the chief organisational leader) a campus climate commission was formed calling for a focus on diversity, student advising, assessment and internationalisation 
(Miller-Jones, 1999). The pursuit of internationalisation had been set, issuing change at many levels of the University:

\section{The 'start-up'}

The start-up is characterized by several sets of activities - most of these launched by senior university leadership.-The University president added 'internationalisation' to the three findings of the Campus Climate Commission (Miller-Jones, 1999) as critical directions for the whole university. This action mobilized resources leading to a series of administrative, staff and faculty efforts, quickly followed by the establishment of the Internationalisation Action Council (IAC) (2001-2002), and a temporary, then permanent position of associate provost for international affairs. The IAC became a faculty/staff internationalisation advocacy group; the position establishing a new senior position on campus. These moves were quickly followed by a faculty mini grant process that distributed seed money (IAC, 2002-2003) to eight faculty-initiated projects, and propelled institutional participation in several regional, national and international collaborations.

\section{Developing sustainable infrastructure for change}

The effort to build a sustainable organisational structure to support internationalisation continued. The newly established IAC and the Office of the Vice Provost for Internationalisation located and documented existing campus resources (e.g. programs, individuals, events) already supporting the goals of the initiative (IAC, 2003-2004). In addition, activities of the IAC became wider known, in part due to the collaboration activities, the mini grants dissemination, and the asset mapping efforts. With additional resources, the campus expanded its visiting professor's program, including some high visibility lectures; and it increased activities that feature international student studying on the campus. During the second year increased funds were allocated for faculty internationalisation mini grants (Internationalization Minigrants, 2002-2003; 20032004), enhanced were travel funds supporting faculty scholarship abroad, and an organisational and physical consolidation of the office of the vice provost for internationalisation into a location of high campus visibility (IAC, 2004-2005). It also saw featured success in campus publications and campus forums (PSU Strategy for Internationalization, 2005).

\section{Enjoying organisational success}

The gains in about a three year period led to some campus euphoria about the internationalisation initiative. The university provost changed and a previous and popular provost returned to serve bringing international experience from his interim two years abroad in Asia. These renewed commitment to internationalisation and also galvanized faculty support. The incumbent provost initialized several globalization discussions (PSU - Fall Symposium Statement, 2005) increasing the visibility of faculty participation (Internationalization Minigrants, 2004-2005), and led to increased consciousness among students that internationalisation involved more options for their own study in addition to wider latitude in on-campus subject matter and curriculum expansion. The study abroad program included research from the several years of previous internationalisation participation. These efforts spilled over into increased representation of internationalisation in assessment and self study, increased depth in globalization discussions in subject fields, and several additional academic units proposed to support increased globalization (Henry, 2005). 
There were those flies in the ointment challenges. First, during the last years a State of Oregon fiscal crisis caused university cutbacks in resources that ultimately affect the most recent of programs and faculty morale to participate in new ideas. Another continuing challenge was the myriad of organisational practices in various units, some of which undermined internationalisation efforts.

\section{Case analysis}

"Scholarship without boundaries encompasses many directions." (NAFSA, 2003) Three significant questions emerge from qualitative analysis of this case: a) Does the data indicate a national perspective congruity with international NAFSA analysis? b) What patterns of behaviour and transformation emerge from the data?; and c) What does this data indicate/mean?

NAFSA (http://capwiz.com/nafsa/home/) is an organisation which has established international norms and analysed the quality of international programs. The PSU activities' congruity with NAFSA internationalisation analysis of campus efforts has been established in eight out of eleven areas by an examination of data including research in progress, the university assessment effort, faculty use of international information in their classrooms, students' use of international information as they become professionals, and graduate students' availability and utilization of internationalisation information, examples and practices in their profession. Overall, the internationalisation effort at Portland State University met most of the NAFSA (2003) description of internationalisation cases around the country.

\section{Case findings}

There are eight patterns emerging from analysis of the case study data:

1) Faculty in internationalisation change resembles 'early adapters' of technology - the literature from studies on technology adaptation appear to indicate that there is a group identified as 'early adapters' as those who appear to effortlessly engage in new behaviour and/or learn a new set of competencies; many may have already supported the change in behaviour or in attitudes prior to the organisational shift. (Taylor, 1997; Schapper \& Mayson, 2004)

2) The organisational dynamic was altered by both top down and bottom up adaptation. The President's initiative sparked change, but that mobilized persons at many levels throughout the organisation.

3) Specific working groups (like the IAC) helped leveraged organisational adaptation, becoming both agent of change and catalyst for further change, as well a visible symbol of the change.

4) Targeted resources played a key role as the organisation shifted resources to activity that supported internationalisation.

5) Curriculum change, a shift in the manifestation of the most fundamental activities of the organisation, continues to be a multi-year process; and while it has responded quickly in public higher education frames of time, the overall change will require more time; perhaps a decade.

6) Information about globalization is not itself enough of a motivator of organisational adaptation. Later adapters must address concerns that have more to do with tradition, habit, past practice, and emotional comfort levels with new practice and roles; which means they are not persuaded to change entirely by new information alone.

7) Internationalisation requires access to transformational experiences including culture contact while living, studying, teaching abroad. For some faculty, hearing the accounts from their peers and students became an interest motivator to participate in an 
international experience. Lack of policy change for travel reimbursement and study abroad appear to have worked against the availability of transformational experiences.

8) To this point, there is incomplete assessment information on what students have educationally gained from the organisation's internationalisation initiative. There are several current underfunded research and evaluation activities being carried out.

These patterns appear to suggest that the PSU campus internationalisation effort has affected structures, roles and the basic mission.

\section{Discussion of findings: cross continent comparisons and imperatives for change}

On these two continents, the historical record suggests higher education changes both on the heels of societal change and as a vehicle for leading that change. In the United States, the $19^{\text {th }}$ century rise of the common school was a function of surges of immigration and a call to a society to reinvent educational access as a form and forum of building an emerging democracy (Tozer, Violas, \& Senese, 2002). The expansion of the width and depth of different missions for higher educational institutions can be seen as a strongly paralleling reaction. Yet, this history is rife with examples of resisting change - often while promoting other changes. This dynamic tension of revisionism and revolution are accelerated by current global trends, which seem to be driven in both directions simultaneously. Marking both the how and the why of change for higher education should be grounded in some understanding that while the tidal forces leading to change are historically unparalleled, and the end game stakes are immeasurably high for each society, clarity about the phenomena is corresponding dim and the prognosis for short-term change is completely out of proportion to the likelihood of predictability of long range hope. The e-learning case in Austria and the internationalisation case in Oregon are significant for two major reasons. They both address two of what Nair (2003) calls imperatives for change in higher education, and they mark revolutions, such as the reconstruction of societal identity, in higher education that are accompanying large-scale cultural changes (Coloma, 2005). In Austria and elsewhere in Europe, the revolution is a movement from higher education's support of a societal privilege status to a more open stance where the technology and new regulations designed for crossing international borders has the affect of crumbling previous barriers to university access including for the disabled and those residing in remote locations. In the United States, the revolution is one where internationalisation challenges major constructs of national identity, exposing existing enviable practice in other societies, and shattering myths that one approach to the creation of a democratic society must prevail over all others.

\section{The language of leadership}

In both situations, leadership played a role in helping the university change. In each case there were policy statements that directly addressed the desired change, and frequently these were couched in terms of which new organisational behaviours were desired outcomes. Language was important in galvanizing groups to engage in action, and in each case the statements of leaders appear to indicate that change will accompany new hope for the institution and better educative service delivery. Language is important for what it does not do: alienate faculty and students, as critical constituents for success of the change. The language also plays an important part in communicating change to the constituent publics.

\section{Hard resource choices}

In each case, the organisational challenge was to alter behaviour by increasing rewards as incentives for programs to move in directions the university wanted to adapt. In 
Austria, additional funds and staff positions urged early technology adapters forward. In the US, the creation of a new high profile deputy provost position was itself a signal that this change was a university priority and also the use of mini grant funds for faculty taken from other university resources added incentives for change.

\section{Midlevel managers}

Higher education tends to overlook or minimize midlevel managers, although they carry the success of the institution on their backs. In each case, the mid level managers played an essential role in the change and may even be said to have influenced the rate of change. Where work as faculty in a university carries high expectation for autonomy, serving as a mid level manager becomes a focal point for the interpretation of larger policy directives, in part because organisational behaviour fills any vacuums that may exist. In Austria, mid level managers and tech as well as didactical support for elearning were critical in facilitating the work of the early adapters. In the US, midlevel academic managers like deans and directors were strategic in encouraging faculty response.

\section{Faculty participation and student needs}

Due to the nature of the higher education enterprise, faculty have traditionally believed that their closeness to students (at least in terms of frequent and intensive contact) hold the keys to higher education responding to perceived student needs. In these cases, a major buy-in point for university faculty has come from their perception that the particular change will also result in gains for students. In Europe, there is acceptance of the continent-wide agreements that students will benefit.

\section{Student response to change}

Like any other group given options, students most likely vote with their feet. They consider - not always deeply - change and new outcomes in light of expanded study opportunities, consumption of resources, and increased life enhancement possibilities. The changes represented by the case studies have the potential to improve students' study possibilities and may lead to better employment or higher life quality options.

Across national boundaries these facets of change can be mentioned: 1) the language of leadership is significant, 2) each organisation finds it must divert resources from other internal sources to assure change, 3) mid-level managers interpretation of senior level directives affect the rate of change, 4) faculty participation is closely tied with student needs, and 5) student enthusiasm for change is not always coupled with student response for the change, in respective universities, appear to be significant.

\section{Examining both cases in light of Asian/Pacific higher education: canaries in the coal mine}

In addition to the patterns of organisational change appearing in the comparison of the two case studies in Innsbruck and Portland, there is a significant metaphorical change that deserves a deeper examination. As was previously stated, in each case of the dual case study, the university change reflects and leads a dynamic alteration occurring in the corresponding society. Further, in each context, the case appears to be an indicator of whether large scale change will continue to occur; or more perversely, be extinguished. This seems to be an important point.

In Europe, the two major changes under way concern access to higher education. The effort to Europeanise and internationalise higher education (Bologna Process and Lifelong Learning Programme 2007-2013 of the European Commission; e.g. 
http://www.lifelonglearningprogramme.org.uk/) as well as the effort to implement standards and guidelines for quality assurance in the EHEA (see e.g. ENQA, 2009), is part of a vast social experiment. Within the next years, the e-learning vehicle carries the potential to create much wider access to the university on a scale not previously encountered. The option of accessing universities by crossing borders for study has been a barrier to access. If the changes described by this case and also the ongoing Lifelong Learning Programme of the European Union are successful, higher education access for a significant portion of the population in Europe will be dramatically affected.

Similarly, expanding post secondary access is dramatic in China, Japan, Pakistan and Australia. In China, for example the 211 Higher Education Development Project from the Ministry of Education has been a key part of the country's re-defining both manpower needs and human capital. According to Li, Whalley, Zhang, and Xiliang (2008) "the number of undergraduate and graduate students in China has been grown at approximately $30 \%$ per year since 1999 , and the number of graduates at all levels of higher education in China has approximately quadrupled in the last 6 years" (much higher than in the OECD) - a movement from an elite system to a mass system. The authors refer to the creation of "significant short term problems of absorption and unemployment for labor" and claim the need of a "wider strategy" in policy making, also "driven by the demand side of labor markets" (ib.). Regarding to such a wider strategy for Europe, the European Commission initiated back to 2000 several linked (also education-oriented) programs within the overall framework of the so-called Lisbon Process (see e.g. http://europa.eu/index_en.htm) as an action and development plan aiming on innovation as motor for economic change, the knowledge-based economy and well as social and environmental renewal.

For Japan, "the [...] government is directing attention to the successes and failures of policy initiatives in Asian and European countries, in addition to considering the results of American policy" (Yonezawa, 2007). Nevertheless, according to the flagship university policy in Asia Yonezawa (2007) claims for a further successful implementation that "[...] a wider policy vision needs to be shared and fostered among institutional leaders as well as policy makers and administrators [...]”. But: Similar to the education policy of the European Union, Japanese universities has also started a more active collaboration with other Asian countries (ib.). Julian Elliott highlighted in his keynote at the APERA ${ }^{1}$ Conference 2008 several risks to Asian education systems; particularly due to a rapid social change-e.g. reduction of teachers' traditional authority based on globalisation influences (see Ng, 2009). Colleagues from public universities in the US also informed me about such a social change-risk in their country-however, I cannot see this tendency for countries in central and Western Europe.

Due to e-learning in the global market, Hezel and Mitchell (2006) state that the United States remains the largest exporter of educational program services. However, Castle, Tyler, Vasquez, and Hieu (2008) argue that "that role is expected to change within the foreseeable future"-they notice a big challenge "notably by emerging programs in India and South Korea".

What about related policy efforts in countries of the Asia-Pacific region?

As part of a distance learning programme, Indonesia tries to connect 32 higher education institutions supported by telecommunication companies. As a long-term goal all of the 200 universities should be networked (Donny \& Mudiardjo, 2008). Nevertheless, similar as for universities of former eastern-European countries, there are different speeds of implementation capabilities (based on financial reasons or the

\footnotetext{
${ }^{1}$ APERA: Asia-Pacific Educational Research Association
} 
reputation of a university). Malaysia's Ministry of Education has initiated a transformation of the education system whereby ICT has become a central concept (Tham \& Kam, 2008; Bakar \& Mohamed, 2008). For the Philippines, the main challenge is to ensure that the ICT efforts "[...] have a meaningful impact on the daily lives of people"-therefore ICT adaption has to be understood as a social process (Salazar, Lardizabal-Vallarino, \& Andam, 2008). In South Korea exists (as in Europe concerning the former Eastern EU-countries) partially a digital divide (Hwang \& Jun, 2008). On the one hand "'education fever' has turned Korea into a global ICT superpower in just 20 years"-on the other hand it still lacks "a policy and strategies for protecting IT users and reducing the digital divide" (ib) and efforts to resolve outstanding social issues (ib.). To bridge such a digital divide is also an important issue in Taiwan's policy-nevertheless, there are (as well as for the European Union countries) efforts to upgrade Taiwan "into one of the leading e-learning and knowledge-based economies" (Liu \& Wang, 2008). Thailand still needs to become a more knowledgebased society and has to address ICT-related challenging issues "in order to get left behind other countries in the region" (Koanantakool \& Udomvitid, 2008). Australia as on the one hand highly urbanized society and on the one hand sparsely populated outside the cities, $32 \%$ of the population hold a university qualification. "Among OECD countries, Australia recorded the second highest level of computer use at school after the United Kingdom" (Ainley, 2009: 75, based on an OECD report of 2005). Since many years both the state and education authorities operated successfully various initiatives for providing students with digital content.

In the United States, the case of internationalisation is also a telling occurrence like the canary in the coal mine. As a result of its particular history, military and political power, geographic isolation and geographic ignorance, the US has frequently exhibited a tendency to function as if it had a monopoly on reasoned action in the world. It has repeatedly pursued such activity in war, commerce, and attempts to create the 'good society', unknowing as if uncaring, about other ways to make policy and run institutions. Internationalisation at public US universities has the potential to remove this shroud of 'ignorance' from a series of 200 year old myths that govern how this nation-state functions. Through internationalisation, understandings, practice and common sensitivity can come to practices and outcomes that are not prevalent at home. Conversely, if internationalisation fails in the university, it raises the possibility that the society will reflect continued ignorance and isolation, particularly when such is not available in the public university where many of the civic leaders of the country are educated. Consequences of failure - the death of this canary in the coal mine would likely be quite apparent. If the canary thrives, new ways to educate, new ways to conduct commerce, new modes of democratic citizenship, and possibly new ways to conduct foreign policy, should emerge.

In each case of the two case studies, the university change is an indicator of the society. In context, each case appears to be an indicator of whether large-scale change will continue to occur; or more perversely, be extinguished.

Acknowledgment. I would like to thank Prof. Samuel D. Henry, Portland State University (PSU), for his advice and helpful discussion of both cases, especially for support regarding the US case. Thanks also to all colleagues for fruitful discussions during my stay at PSU in summer 2008. 


\section{References}

Ainley, J. (2009). National Policies and Practices on ICT in Education: Australia. In T. Pomp, R.E. Anderson, N. Law, \& A. Quale (Eds), Cross-National Information and Communication Technology. Policies and Practices in Education (67-82). Greenwich, Connecticut: Information Age Publishing.

Altbach, P.G. (Ed.) (2000). The Changing Academic Workplace: Comparative Perspectives. Chestnut Hill, MA: Center for International Higher Education, Boston College.

Altbach, P.G. \& Peterson, M.G. P. (1999). Higher education in the $21^{\text {st }}$ century: Global challenge and national response. IIE Research Report No. 29, 3-10. Retrieved May 15, 2009, from http://www.bc.edu/bc org/avp/soe/cihe/pga/pdf/IIE\%20Altbach-

Peterson\%20Book.pdf $\#$ page $=10$

Anchan, J.P. (2006). Education in India: Progress and Promise in a Land of Paradox. In K. Mazurek \& M.A. Winzer (Eds.), Schooling around the World - Debates, Challenges, And Practices (192(13)-203(1)). Boston, MA: Pearson/Allyn and Bacon.

Bakar, A.R. \& Mohamed, S. (2008). Teaching using information and communication technology: Do trainee teachers have the confidence? International Journal of Education and Development using ICT, 4(1). Retrieved April 4, 2009, from http://ijedict.dec.uwi.edu/viewarticle.php?id=374\&layout=html

Biedermann, H. \& Strehl, F. (2004). Leistungsvereinbarung. In S. Höllinger \& S. Titscher (Eds.), Die österreichische Universitätsreform. Zur Implementierung des Universitätsgesetzes 2002 (219245), Vienna: WUV Verlag.

Cardoso, R., Porela, M., Sá, C, \& Alexandre, F. (2008). Demand for Higher Education Programs: The Impact of the Bologna Process. CESifo Economic Studies, 54(2), 229-247.

Castle, S.R., Tyler, C., Vasquez, M., \& Hieu, D.T.M. (2008). Global E-Learning: Both a Necessity and Challenge for U.S. Institutions of Higher Education. E-leader 2008 (January 2-4, 2008). Retrieved May 25, 2009, from http://www.gcasa.com/PDF/Bangkok\%202008/Castle\%20Bangkok, \%202008.pdf

Coloma, R.S. (2005). Disidentifying nationalism: Camilo Osias and filipino education in the early twentieth century. In E. T. Ewing (Ed.), Revolution and pedagogy: interdisciplinary and transnational perspectives on educational foundations (19-38). New York: Palgarave McMillian.

Damme van, D. (2009). The Search of Transparency: Convergence and Diversity in the Bologna Process. In F.A. van Vught (Ed.), Mapping the Higher Education Landscape. Towards a European Classification of Higher Education (39-55). AZ Dordrecht: Springer.

Deem, R., Mok, K.H., \& Lucas, L. (2008). Transforming Higher Education in Whose Image? Exploring the Concept of the 'World-Class' University in Europe and Asia. Higher Education Policy, 21, 83-97.

Dittler, M. \& Bachmann, G. (2003). Entscheidungsprozesse und Begleitmaßnahmen bei der Auswahl und Einführung von Lernplattformen. In K. Bett \& J. Wedekind (Eds.), Lernplattformen in der Praxis (pp. 175-192, Vol. 20). Münster: Waxmann.

Donny, B.U. \& Mudiardjo, R. (2008). Indonesia. In F. Librero \& P.B. Arinto (Eds.), Digital Review of AsiaPacific 2007-2008 (pp. 161-171). New Delhi: Sage.

Enders, J. (2000). Academic Staff in Europe: Changing Employment and Working Conditions. In M. Tight (Ed.), Academic Work and Life (pp. 7-32). Amsterdam: Elsevier.

ENQA (2009). Standards and Guidelines for Quality Assurance in the European Higher Education Area. Report. DG Education and Culture. Helsiniki: European Association for Quality Assurance in Higher Education. Retrieved May 9, 2009, from http://www.enqa.eu/files/ESG_3edition (2).pdf

Eurydice (2005). Focus on the Structure of Higher Education in Europe 2006/07. National Trends in the Bologna Process. European Commission.

European Commission (2005). Realising the European Higher Education Area - Achieving the Goals. Conference of European Higher Education Ministers, Contribution of the European Commission. Bergen, 19-20 May 2005.

European Union (2004). ECTS Users' Guide. European Credit Transfer and Accumulation System and the Diploma Supplement. Directorate-General for Education and Culture. Brussels, 17 August 2004.

Fejes, A. (2008). European citizens under construction - the Bologna process analysed from a governmentality perspective. Educational Philosophie and Theory, 40(4), 515-530. 
Frisbee, D. (1989). The governor's report on higher education in the Portland metro area. State of Oregon.

Hawkins, J.N. (2008). Higher Education Transformation: some trends in California and Asia. Policy Futures in Education, 6(5), 532-544.

Henry, S.D. (2005). Report to the PSU Internationalization Action Council on Minigrants. May 2005.

Hezel, R.T. \& Mitchell, J. (2006). Developing a Global E-Learning Program: From Conceptualization to Implementation. Hezel Associates, Syracuse, NJ: LLC.

Höllinger, S. (2004). Die Entwicklung von der staatlich gelenkten zur autonomen und europäischen Universität. In S. Höllinger \& S. Titscher (Eds.), Die österreichische Universitätsreform. Zur Implementierung des Universitätsgesetzes 2002. Vienna: WUV Verlag.

Hwang, J.S. \& Jun, J. (2008). South Korea. In F. Librero \& P.B. Arinto (Eds.), Digital Review of AsiaPacific 2007-2008 (289-295). New Delhi: Sage.

IAC (Internationalization Action Council) (2001-2002). Working Group, President's Corner, Portland State University. Retrieved November 14, 2008, from www.president.pdx.edu/Initiatives/intrnational/rec\&actions01.phtml

IAC (Internationalization Action Council) (2004-2005). Portland State University. Retrieved June 17, 2008, from www.president.pdx.edu/Initiatives/international/intcouncil.phtml

Internationalization Minigrants (2002-2003). Internationalization Council. Portland State University. $\begin{array}{llll}\text { Retrieved } \quad \text { September } & 17, & \text { 2008, from }\end{array}$ www.president.pdx.edu/Initiatives/international/grants0203.html

Internationalization Minigrants (2003-2004). Internationalization Council. Portland State University. $\begin{array}{llll}\text { Retrieved } \quad \text { October } & \text { 2008, from }\end{array}$ www.president.pdx.edu/Initiatives/international/grants0304.html

Internationalization Minigrants (2004-2005). Internationalization Council. Portland State University. Retrieved October 17, 2008, from www.president.pdx.edu/Initiatives/international/grants0405.html

Jakobi, A.P. \& Rusconi, A. (2009). Lifelong learning in the Bologna process: European developments in higher education. Compare: A Journal of Comparative and International Education, 39(1), $51-65$.

Jung, D. (2006). Education in South Korea: Changes and Challenges. In K. Mazurek \& M.A. Winzer (Eds.), Schooling around the World - Debates, Challenges, And Practices (pp. 52(16)-67(1)). Boston, MA: Pearson/Allyn and Bacon.

Kasparovsky, H. \& Wadsack, I. (2004). Higher Education in Austria. Austrian Federal Ministry of Education, Science and Culture. (July 2004) Vienna. Retrieved November 21, 2008, from www.bmbwk.gv.at

Koanantakool, T. \& Udomvitid, K. (2008). Thailand. In F. Librero \& P.B. Arinto (Eds.), Digital Review of AsiaPacific 2007-2008 (313-320). New Delhi: Sage.

Law, W.-W. (2006). Education Reform for National Competitiveness in a Global Age: The Experience and Struggle of China. In K. Mazurek \& M.A. Winzer (Eds.), Schooling around the World Debates, Challenges, And Practices (pp. 68(36)-99(5)). Boston, MA: Pearson/Allyn and Bacon.

Lee, M. N. N. (2004). Global Trends, National Policies and Institutional Responses: Restructuring Higher Education in Malaysia. Educational Research for Policy and Practice 3, 31-46.

Lee, W. O. (2008). The repositioning of high education from its expanded visions: lifelong learning, entrepreneurship, internationalization and integration. Educational Research for Policy and Practice, 7, 73-83.

Leuven Communiqué (2009). The Bologna Process 2020 - The European Higher Education Area in the new decade. Communiqué of the Conference of European Ministers Responsible for Higher Education, Leuven and Louvain-la-Neuve, 28-29 April 2009. Retrieved April 5, 2009, from

http://www.ond.vlaanderen.be/hogeronderwijs/bologna/conference/documents/Leuven_Louva in-la-Neuve Communiqu\%C3\%A9 April 2009.pdf

Li, Y., Whalley, J., Zhang, S., \& Xiliang, Z. (2008). The Higher Education Transformation of China and ist Global Implications. NBER Working Paper No. W13849, issued in March 2008. Retrieved May 10, 2009, from http://www.nber.org/papers/w13849

Liu, Y. \& Wang, E.H. (2008). Taiwan. In F. Librero \& P.B. Arinto (Eds.), Digital Review of AsiaPacific 2007-2008 (pp. 304-312). New Delhi: Sage.

Martínez, R. J. \& Moreno, R. (2007). Validity of academic work indicators in the projected European Higher Education Area. Higher Education, 53, 739-747. 
McLendon, M.K. (2003). State Governance Reform of Higher Education: Patterns, Trends, and Theories of the Public Policy Process. In J.C. Smart \& W.G. Tierney (Eds.), Higher Education. Handbook of Theory and Research (Vol. XVIII, September 2003, 18-2: 86 pages). New York Agathon Press.

Mechtenberg, L. \& Strausz, R. (2008). The Bologna process: how student mobility affects multicultural skills and educational quality. International Tax and Public Finance, 15(2), 109-130.

Melchior, J. (2004). The profession: the managerial and entrepreneurial turn in Austrian higher Education. European Political Science - Summer 2004, No. 3.3. European Consortium for Political Research. Retrieved December 15, 2008, from www.essex.ac.uk/ECPR/publications

Miller-Jones, D. (1999). The Campus Climate Commission Report. Portland State University.

Nair, P. (2003). Imperatives for Change in Higher Education: Planning the Future of the American Campus. (Report No. REIDEC2003). Minneapolis, MN: Design Share. (ERIC Document Reproduction Service No. ED475500).

NAFSA (2003). Internationalizing the campus: profiles of success at colleges and universities. Washington, D.C.: Association of International Educators. New Delhi: Sage.

Nieto, S. (2004) Affirming Diversity: The Sociopolitical Context of Multicultural Education. Boston: Allyn \& Bacon.

Ng, P.T. (2009). Educational research for innovation and quality in education: a report of the AsiaPacific Educational Research Association (APERA) conference 2008. Educational Research for Policy and Practice, 8, 73-77.

Park, J. \& Niyozov, S. (2008). Madrasa education in South Asia and Southeast Asia: current issues and debates. Asia Pacific Journal of Education, 28(4), 323-351.

Pechar, H. (2005). University Autonomy in Austria. Higher Education Research - HOFO Working Paper Series: IFF_hofo.05.001. IFF (Faculty for Interdisciplinary Studies). Vienna. Retrieved January 5, 2009, from http://www.iff.ac.at/hofo/WP/IFF hofo.05.001 pechar autonomy.pdf

Power, C. (2009). Asia and the Pacific in 2020: scenarios for educational research. Educational Research for Policy and Practice, DOI 10.1007/s10671-009-9063-8 (published online first: February 14, 2009).

PSU Strategy for Internationalization (2005). Office of the President. Portland State University.

PSU - Fall Symposium Statement (2005). The Office of International Affairs and the Office of the Provost. Portland State University. PSU Internationalization Goals as of 6/04/03, Internationalization Action Council. Retrieved June 17, 2008, from www.president.pdx.edu/Initiatives/international/intlgoals.phtml

Ravinet, P. (2008). From Voluntary Participation to Monitored Coordination: why European countries feel increasingly bound by their commitment to the Bologna Process. European Journal of Education, 43(3), 353-367.

Riaz, M. (2006). Education Systems in an Ideological State: Major Issues and Concerns in Pakistan. In K. Mazurek \& M.A. Winzer (Eds.), Schooling around the World - Debates, Challenges, And Practices (pp. 168(24)-190(2)). Boston, MA: Pearson/Allyn and Bacon.

Rice, R. E. (1986). The academic profession in transition: Toward a new social fiction. Teaching Sociology, 14, 12-23.

Salazar, L.C., Lardizabal-Vallarino, S., \& Andam, Z.R. (2008). Philippines. In F. Librero \& P.B. Arinto (Eds.), Digital Review of AsiaPacific 2007-2008 (pp. 268-277). New Delhi: Sage.

Schapper, J.M. \& Mayson, S.E. (2004). Internationalization of curricula: an alternative to the Taylorisation of academic work. Journal of Higher Education Policy and Management, 26(2), 189-205.

Shattock, M. (2000). The academic profession in Britain: A study in the failure to adapt to change, in The Changing Academic Workplace. Chestnut Hill, MA: Center for International Higher Education, Boston College.

Taylor, P.G. (1997). Creating environments which nurture development: messages from research into academics' experiences. International Journal for Academic Development, 2(2), 42-49.

Tham, S.Y. \& Kam, A.J.Y. (2008). Internationalising higher education: comparing the challenges of different higher education institutions in Malaysia. Asia Pacific Journal of Education, 28(4), 353-367.

Titscher, S. (2004). Profilbildung an österreichischen Universitäten. In S. Höllinger \& S. Titscher (Eds.), Die österreichische Universitätsreform. Zur Implementierung des Universitätsgesetzes 2002. Vienna: WUV Verlag.

Tozer, S., Violas, P.C., \& Senese, G. (2002). School and society: historical and contemporary perspectives. Boston: McGraw Hill. 
Universities Act 2002 (2002). Federal Act on the Organisation of the Universities and their Studies. National Council. Austria, Vienna. Retrieved March 20, 2009, from http://www.cepes.ro/hed/policy/legislation/pdf/Austria.pdf

Vlâsceanu, L., \& Voicu, B. (2006). Implementation of the Bologna Objectives in a Sample of European Private Higher Education Institutions: Outcomes of a Survey. Higher Education in Europe, 31(1), 25-52.

Willis, D.B., Yamamura, S., \& Rappleye, J. (2008). Frontiers of education: Japan as "global model" or "nation at riks"? International Review of Education, 54, 493-515.

Yonezawa, A. (2003). The Impact of Globalization on Higher Education Governance in Japan. Higher Education Research \& Development, 22(2), 145-154. 